\title{
FGFR Gene Amplification
}

National Cancer Institute

\section{Source}

National Cancer Institute. FGFR Gene Amplification. NCI Thesaurus. Code C118378.

A molecular genetic abnormality indicating the presence of multiple copies of an FGFR family gene. 